departments and by the Medical and the Agricultural Research Councils, in addition to a certain amount directly aimed at the control of conception, carried out by industrial cnterprises. The Government would always be ready to accede to requests for help from Governments under tho Colombo Plan. However, until such requests for technical assistance were received, Britain's main contribution to the problem of over-population should be to continue to give maximum support to the existing programme of capital aid and technical assistance. Such programmes would leave the Governments concerned free to judge how the help given could be best applied to overcome poverty and ignorance.

\section{Forestry in Britain}

IN his address to the Royal Society of Arts on the subject of forestry (the second of three Cantor Lectures on the Development of Natural Resources, May 14, 1962), Mr. James Macdonald, deputy directorgeneral of the Forestry Commission, dealt first of all with the productive side of forestry. Only some 7 per cent of Britain's land surface is covered with forests, which is a low figure compared with many European countries. The tree line in Britain is relatively low and exposure may be severe, thus preventing the use for forestry purposes of localities which would otherwise be suitable. On the other hand, tree growth in some localities is faster than on the Continent. As a result of plantings during the past forty years, the acreage under conifers (all exotic except the Scots pine) has inereased and that under hardwoods has diminished. The distribution of age-classes is not ideal, there beirg an over-abundance of old hardwoods and a deficiency of old conifers. However, this state of affairs will be adjusted before vory long, particularly with the conifers which are grown on shorter rotations than the hardwoods. It is considered that in the next seventy years production will be doubled from private forests and trebled from Forestry Commission forests. This increased production will be required in Britain, which in 1960 imported $£ 456$ million of timber. According to investigations by the Food and Agriculture Organ. ization, the increasing deficit in the supply of timber will continue for the next few decades and there are some North American authorities who consider it probable that there will be no exportable surplus of timber from that continent by the end of the century. Forestry has an important part to play in upland areas in Britain, where it can increase production from the land and also help other land users with better communications and better grazing conditions without any diminution of livestock. The National Forest Parks provide facilities for recreation without interfering with the continued practice of forestry. Forests are also a haven for wild-lifo and thus help in its preservation. Mr. Macdonald ended his talk by referring to the multiple uses of forestry in Britain, some of which are assessable in cash while others are not, but both private and Stato forests "ropresent a substantial contribution to national resources and a contribution which is growing greater year by year".

\section{Materials Research}

The first number of a new international quarterly, Materials Research, was published in April (1, No. 1; April 1962. Published quarterly. Annual subscription f5. London: Heywood and Co. Ltd., 1962). The editors are Dr. F. G. Stanford (Banbury), Prof. T. J. Dolan (Illinois) and Prof.
P. G. Bastien (Paris). Papers are in English, but abstracts of all the papers are printed in English, French, German, Italian and Russian. The sub-title of the periodical is "An International Journal of the Properties and Testing of Engineering Materials", and on the evidence of the seven papers included in the first issue, the emphasis is to be evonly distributed between these two fields. One group of papers is concerned with the use of ultrasonic flaw-testing equipment and with a rapid induction method for measuring electrical conductivity, while the other research papers deal with creep, notch-brittleness and an engineering aspect of fatigue. One of the declared aims of the periodical is to analyso the reasons for the particular properties of various materials. This aim has been pursued in an introductory review paper, which attempts a survey of the properties of metals in terms of crystal structure and two-phase distributions. In the light of this first issue, it appcars likely that the journal will concern itself with comparatively empirical studies of engineering materials, together with an intensive examination of modern methods of materials testing and inspection. Since there is a shortage of journals dealing with testing methods, it is to be hoped that the editors will continue to give considerable space to good papers in this important field.

\section{Topology}

Is the course of this century, topology has grown from some isolated and special problems into one of the major disciplines of modern mathematies, with a considerable terminology and an array of methods which are influencing almost every other branch of the subject. The untimely death of that great topologist, Henry Whitehead, has fortunately not prevented his project of an international journal for topology from coming to fruition, thanks to the scientific enterprise of the Pergamon Press (Topology, Vol. 1; January-March, 1962. An International Journal of Mathematies founded by J. H. C. Whitehead, Oxford. Pp. 80. Published four times yearly. London and New York: Pergamon Press, 1962. Annual subscription rates: $A$, for libraries, govern. ment establishments, research laboratories, etc., $£ 10$ or 30 dollars; $B$, for individuals who place their orders directly with the publisher and certify that the journal is for their personal use, $£ 310 s$. or 10 dollars). The new journal is a quarterly, and the first part appeared in the spring of this year. There is a strong editorial board consisting of $\mathbf{M}$. F. Atiyah (Oxford), R. Bott (Harvard), F. Hirzebruch (Bonn), I. M. James (Oxford), R. Thom (Strasbourg), and an editorial advisory board of great distinction: $\boldsymbol{H}$. Cartan (Paris), K. Kuratowski (Warsaw), M. H. A. Newman (Manchester), H. Seifert (Heidelberg), N. F. Steenrod (Princeton).

\section{South African Museum, Cape Town}

To an increasing extent museums are now seeking to advance knowledge by research and publication, and this is in addition to their previous functions of acquisition and conservation. In a recent issue of Annals of the South African Museum (46, Part 9: On the Dentition and Tooth Replacement in Two Bauriamorph Reptiles. Pp. 231-256+plates 12-14. Cape Town: South African Museum, 1962. 52 cents), Dr. A. W. Crompton gives the results of his researches on the dentition and tooth replacoment in two Bauriamorph reptiles (Ericiolacerta parva and Bauria cynops). He finds that alternate tooth replacement 